\title{
LA NOVELA COMO GÉNERO LITERARIO EN EL SIGLO XVII EN FRANCIA
}

\author{
Miguel Angel García Peinado* \\ Universidad de Córdoba
}

\begin{abstract}
RESUMEN. El presente artículo trata de la formación de la novela como género literario en Francia en el siglo XVII. Después de una introducción a la noción de género literario, partiendo de la Poética de Aristóteles, se ocupa del estudio de la novela que a pesar de no gozar de entrada del status de género se ha convertido en el género por excelencia. Un breve repaso a los antecedentes italianos y españoles, con mención especial a Cervantes, da paso al desarrollo de la novela en Francia basado fundamentalmente en el discurso teórico que los autores generan sobre su propia producción en los Préfaces, Avertissements, Avis au lecteur, etc. Esta relación extradiegética que mantiene el autor con su relato va configurando, a lo largo del siglo, una historia de la novelística escrita por los propios autores que tratan de imponer su criterio ante los lectores así como su propia labor de creación.
\end{abstract}

ABSTRACT. This paper deals with the configuration of the novel as a literary genre in France during the 17th century. After a brief introduction to the concept of literary genre, with Aristotle's Poetics as the main source, it deals with the study of the novel as a genre that, although it did not posses a fixed status in its origins, it had become by the 17th century the genre par excellence. A brief survey of the Italian and Spanish forerunners, with a special reference to Cervantes, leads to the study of the development of the novel in France, which is mainly based on the theoretical discourse that the authors brought about within their own production, in Préfaces, Avertissements, Avis au lecteur, etc. This "extradiegétique" relationship that the autor keeps with his/her narrative gives shape, throughout the century, to a history of the novel written by authors who strive to impose both their criteria and their own creative principles on the readers.

\section{Introducción: los géneros literarios}

Es notorio que la Poética de Aristóteles ha sido considerada como la primera gran teoría de los géneros literarios y uno de los dos intentos de sistematización estéti-

\footnotetext{
* Catedrático de Filología Francesa en el Dpto. de Filologías Francesa e Inglesa de la Facultad de Filosofía y Letras.
} 
ca en la época clásica. ${ }^{1}$ En sus veintiseis capítulos la obra adolece de esquemática, no estar sujeta a un rígido orden exterior, estar llena de interrupciones, de paréntesis, de sobreentendidos, de elipsis, etc. Dejando a un lado la cuestión tan debatida de si la obra estaba compuesta por uno o dos libros, ${ }^{2}$ digamos que Aristóteles trata en la Poética fundamentalmente de la tragedia. En los cinco primeros capítulos, a modo de introducción, se plantea el problema del arte como "imitación”, término que procede de Platón y que quizá debería interpretarse en Aristóteles como "representación". En el capítulo seis se encuentra la definición de la tragedia y la enumeración de sus seis elementos constitutivos: fábula o argumento, caracteres, elocución, pensamiento, espectáculo y melopeya. Los capítulos siete al catorce están relacionados con la trama su estructura y sus efectos emocionales, enumerando en el doce las partes formales de la tragedia: prólogo, episodio, éxodo y parte coral, y ocupándose también, ya desde el trece y hasta el diecinueve, del estudio de los caracteres y de los contenidos de composición y temor desde el punto de vista de la causalidad. El capítulo veinte nos presenta las partes del lenguaje como formas que estructuran el significante y la descripción razonada de la poesía y la prosa. El veintiuno y veintidos tratan de la palabra como elemento de la elocución y su aplicación. Los capítulos veintitres y veinticuatro tratan de la epopeya: de la unidad de acción y de sus especies y partes. El veinticinco, sin una relación de continuidad con los anteriores, trata de problemas críticos y sus soluciones. Por último, el veintiseis resuelve la cuestión de la superioridad de epopeya o tragedia, inclinándose por ésta.

Aristóteles se enfrenta con los géneros como divisiones empíricas de las obras que se dan en su tiempo y procede delimitando las obras de arte literario de las demás artes. Para él son géneros literarios los que utilizan la lengua natural. Es interesante el hecho de que el autor de la Poética diferencia por el "modo de imitar" dos apartados: la narración y el drama (capítulo $3^{\circ}$ ) estableciendo en cada uno de ellos subdivisiones. Podemos constatar como el autor pretende realizar una clasificación de las obras más bien para ejercer la crítica literaria que para proponer un esquema de las posibilidades de creación. Así, la épica y la dramática son las dos fórmulas fundamentales del arte "realizado con palabras" en su momento y a ellas se atiene.

Por lo que respecta a los criterios aristotélicos para clasificar los géneros literarios son fundamentalmente de tres tipos: de contenido, formales y discursivos. En cuanto al carácter "literario" de los géneros frente a los "géneros no literarios", Aristóteles diferencia la poesía (obra de creación) y la historia basándose en que no corresponde al poeta decir lo que ha sucedido sino lo que podría suceder.

El modelo de la Poética aristotélica es un modelo histórico, hecho para un tiempo y basado en él, del mismo modo que la clasificación por géneros literarios va unida

1. El otro es La República de Platón.

2. Los indicios más lógicos inducen a pensar que el segundo e inexistente volumen trataría de la comedia, en paralelismo con el primero que trata de la tragedia. 
indisolublemente a la historia de las series de modelos estilísticos que han tenido una vigencia y que han desaparecido. De cualquier modo, es innegable que Aristóteles es el primero que "piensa la poética como una ciencia de la literatura", como un arte que imita sólo con el lenguaje; es el iniciador de la ciencia de la literatura y el primer teorizador de ella.

La división por géneros parece, aún hoy y con sus lógicas variantes respecto a la desaparición de unos y la aparición de otros nuevos, la más intrínseca de cuantas se puedan establecer en la literatura. Si las clasificaciones por escuelas, generaciones, movimientos, épocas, etc., están ligadas con el objeto literario, es a través de la institución del género o del discours como prefiere llamarlo Roland Barthes, quien al buscar una objetivación lingüística ve en la palabra géneros un concepto demasiado ambiguo y prefiere hablar de discurso, es decir de "conjunto de palabras superiores a la frase”. Dentro de la crítica estructural-formalista francesa o crítica narratológica, Genette y Todorov son los que más se han ocupado del problema de los géneros literarios, siendo el último quien lo afronta desde una perspectiva más tradicional. En opinión de Todorov lo primero es dejar de identificar los géneros con los nombres de los géneros, ya que es evidente que si el concepto de género debe tener un papel en la teoría del lenguaje literario, no podemos definirlo basándonos únicamente en las denominaciones, pues algunos géneros nunca han recibido nombre y otros han sido confundidos bajo un nombre único a pesar de sus diferencias intrínsecas. Así pues, el estudio de los géneros debe realizarse a partir de las características estructurales y no a partir de sus nombres. Por su parte Genette se ocupa ampliamente del problema en su Introduction à l'architexte (Paris, Seuil, 1979) ya que la base del libro es la disertación sobre géneros, tipos y modos. La teoría de Genette es la piedra angular sobre la que se apoya la crítica actual al plantear cualquier revisión de los géneros y su identidad. Sin desdeñar el componente de lo histórico ni el de la naturaleza, Genette rechaza lo que denomina el privilegio clásico de la naturalidad que dio lugar a tres modos (narración formal, narración mixta, imitación dramática) sobre los que basa la distinción de tres géneros o archigéneros (lirismo, epopeya, drama), que no existen ni pueden existir. Hay que hablar de modos (como el relato) o de géneros (como la novela). Los géneros, por supuesto, pueden mezclarse con los modos (no en el sentido de inclusión aristotélica) y las obras imbricarse en los géneros.

Digamos, asimismo, que han existido dos aproximaciones radicalmente diferentes a través de la historia: una, inductiva, ha constatado la existencia de los géneros partiendo de la observación de un período dado; otra, deductiva, ha postulado la existencia de los géneros a partir de una teoría del discurso literario. Las divergencias han sido tan grandes que casi se podría hablar de géneros en el primer caso y de tipos en el segundo. Esta diferencia entre género y tipo reaparece cuando observamos la relación de uno y otro respecto a la obra individual.

Entre las clasificaciones más notables de los géneros literarios Todorov cita las conocidas de: prosa-poesía, lírica-épica-dramática, tragedia-comedia y la teoría de los 
tres estilos (elevado, medio, bajo); a pesar de ello Todorov es consciente de que ya no se habla de poesía y de prosa, de testimonio y de ficción, sino de novela y de relato, de lo narrativo y de lo discursivo.

Los estudios más recientes sobre los géneros literarios insisten en tener en cuenta la historia de éstos para que se pueda distinguir entre géneros teóricos y géneros históricos, ya que hacer abstracción de la historia conlleva el riesgo de hacer perder su especialidad a la literatura. En su obra ya citada, Introduction à l'architexte, Genette muestra cuán decepcionantes son las construcciones puramente teóricas, con frecuencia ineficaces en el momento de explicar la realidad. El género está sometido a una serie de presiones que emanan, por una parte, del macrocontexto socio-cultural y, por otra, a presiones en el interior del contexto literario. Por esta razón los géneros no podrían existir fuera de la historia: gracias a ésta se transforman, en la medida en que participan de ella, inscribiéndose en la historia en la medida en que se transforman. ${ }^{3}$

\section{La novela ¿Género literario?}

La interrogación no parece inadecuada ni gratuita ya que en relación con la novela la teoría de la literatura muestra una impotencia total; es cierto que la novela se encuentra en un sentido latente en las teorías antiguas como un conjunto no totalizable de nociones, esquemas y preceptos a partir de los cuales en un momento dado irá emergiendo en el instante en que se den las condiciones favorables para su aparición, su desarrollo y su toma de conciencia como género. Estos tres grandes momentos, que se pueden identificar con épocas concretas, así como el largo proceso de "refundición" de otros géneros próximos a ella, propician que el autor vaya reafirmando sus propias espectativas y que su propia ética se convierta en un problema estético de la obra.

A pesar de esta auto-afirmación que inconscientemente se ha producido en la novela, el estudio de ésta como género ha chocado tradicionalmente con una serie de dificultades especiales que vienen determinadas por la especificidad misma del objeto: la novela es el único género en continuo proceso de formación, jamás consolidado, ya que su estructura varía de un modo tan imprevisible que hace prácticamente imposible imaginar su futuro.

A otros géneros los conocemos como formas fijas que son y con un aspecto limitado; así, la epopeya no sólo aparece como un género acabado, sino como un género profundamente envejecido. Lo mismo se puede decir, con algunas reservas, de otros géneros esenciales, incluida la tragedia. Su existencia histórica es la de géneros acabados, con una estructura firme y poco maleable; en cambio en la novela sólo determina-

3. Todas estas "presiones" sociales y literarias, así como la singularidad de cada autor, justifican el hecho de que no haya géneros puros, que se interpreten unos en otros, como el ensayo y el cuento en Borges, por ejemplo. 
dos modelos de ella son históricamente duraderos, pero no el canon del género como tal. En este hecho estriba la gran dificultad para desarrollar una teoría novelística, ya que esa teoría tiene como objeto de estudio algo que es completamente diferente al de la teoría de otros géneros. Dicho de otro modo, la novela no es simplemente un género entre otros géneros sino que es el único género en continuo proceso de formación y además el único género producido y alimentado por la época moderna de la historia del mundo.

Esta supremacía sobre los restantes géneros, gracias a una constante adaptación a los tiempos así como a las continuas técnicas de que se nutre, hace que, de un modo insconciente, la novela parodie otros géneros -siempre en su calidad de géneros- y que desvele el convencionalismo de sus formas y su lenguaje. Es fácilmente observable el hecho de que en las épocas en que la novela se convierte en un género predominante, toda la literatura se vea implicada en una especie de "crítica de los géneros"; esto podemos apreciarlo de un modo muy claro en la segunda mitad del siglo XVIII. No es menos cierto que en las épocas de dominio de la novela sobre los demás géneros éstos adquieran características típicas e inherentes a ella; esto, que podría parecer totalmente positivo, encierra una parte de imperfección. Desde el momento en que la novela se convierte en protagonista principal del drama de la evolución literaria de los tiempos modernos la novela anticipa, en muchos aspectos, la futura evolución de toda la literatura; así pues, al alcanzar la supremacía contribuye a la renovación de los demás géneros pero les contagia el proceso de formación y las imperfecciones propias.

Es sabido que en toda obra literaria hay dos fenómenos que relacionan al texto y al lector: un camino de ida y otro de vuelta, esto es, la proyección transpositiva del lector al mundo de la narración, con la que se identifica y la interpretación paradigmática del mundo de la ficción para explicar o justificar el mundo del lector o el mundo real. En la novela parece ser mucho más fuerte el segundo proceso que el primero y adquiere una validez mucho más amplia que en otros géneros: el carácter paradigmático de la obra novelesca, la aplicación de su contenido al exterior, que se da en el verso, lleva a la utilización de la novela como arma polémica ${ }^{4}$.

Esta distinción podemos utilizarla para mostrar las diferencias que separan la novela de lo que tantas veces se ha señalado como su origen y ya hemos citado anteriormente: la epopeya heroica. En ésta, fundamentalmente, es imposible la utilización paradigmática en cuanto el héroe es un ser excepcional: ni él ni sus hechos caben en la realidad objetiva, por eso se presenta en forma versificada. No se trata de que un héroe de novela no pueda ser ni actuar como uno de epopeya, que sí puede; pero en la epopeya se propone un caso, que se sale de las normas y en el que los hechos sólo pueden ser atribuidos a un tipo de individuos: los héroes, cosa que no ocurre en la novela. La

4. El teatro ocuparía aquí una posición intermedia, en la que se da tanto la catarsis como la utilización polémica. 
aparición del héroe de la epopeya no invalida las leyes de la realidad, lo que hace es sacar al personaje de ese plano.

Por otra parte, y volviendo a la comparación con el verso o la literatura dramática, la novela, por su ausencia de marca, no presenta un caso fuera de las reglas que rigen la realidad ni como caso válido en una realidad particularizada. La novela presenta una realidad completa; totalizaría la totalidad, si por tal se entendiera la identificación de una teoría con su praxis, como realidad unitaria. La ambigüedad del procedimiento novelesco es esencial al género, como lo es al teatro la carencia y a la poesía la redundancia. La ambigüedad aparece porque el texto novelesco es al mismo tiempo teoría y praxis: es el contenido de la novela lo que organiza y presenta sus materiales de acuerdo con los presupuestos que rigen, en un momento histórico y entre un grupo, la comprensión de la realidad objetiva.

En este aspecto, la novela cumple una función clasificadora culturalmente, entendiendo por tal el aspecto intelectual del medio artificial que el hombre se crea a lo largo de su vida social. Digamos, a este respecto, que los problemas del medio ambiente o social,que son literariamente fructíferos, están vinculados a ideas y opiniones que, ciertamente, no tienen por qué haber sido acuñadas siempre en el siglo XIX, aunque éste las haya tratado y expuesto con creciente decisión. A ellas pertenece, por ejemplo, la convicción de que el ser humano puede ser bien un objeto que padece bajo su entorno, bien un sujeto configurador del mismo; la convicción de que cada individuo es capaz de crearse su entorno y su mundo propios, de que no puede haber un entorno absolutamente idéntico para todos los hombres del mismo ambiente y, por tanto, que puede haber una visión subjetivamente muy diferente de un solo y mismo medio ambiente; la observación de que el primer medio ambiente que establece normas de conducta es el reducido círculo de la familia y que determinados valores e ideales son dependientes no sólo de la época, sino también condicionados por el medio social; la convicción, hija de la experiencia, de que las deficiencias e incluso anomalías en el desarrollo de la personalidad dependen a veces de los factores del medio ambiente y que un cambio de éste puede ser utilísimo remedio. Hecha esta salvedad, creemos que la novela ayuda a entender no tanto la realidad como el sistema intelectual mediante el cual se relaciona el hombre con la realidad. Sirve de esta manera también como medio de reconocimiento para el grupo que se auto-representa en ella; la presentación de esos sistemas como vivencias sirve para crear o reforzar la cohesión ideológica del grupo (esta es su función social). Así pues, no parece pertinente adscribir la novela, como género, a una clase social.

Naturalmente, las diferencias dentro del género que llamamos novela pueden ser muchas y muy variadas. Se puede pensar, por otra parte, que en el interior del género hay marcas que establecen subdivisiones; en efecto, las hay pero no son tanto marcas formales como conceptuales, dependen del contenido de las palabras no de la forma. Otros rasgos distintivos son formales: la ausencia de capítulos, de párrafos, de signos de puntuación y hasta de encuadernación a veces; sin embargo, todos estos rasgos no 
sirven para señalar géneros aparte si siguen conservando su carácter, esto es, esas variaciones formales corresponden a variaciones paralelas en las obras producidas por la mentalidad objetiva de la época.

\section{Antecedentes italianos y españoles}

La noción de género, que en el fondo no era más que el reagrupamiento bajo una misma etiqueta de trozos literarios de naturaleza semejante -bien sea por la forma o bien por el contenido-, pareció perder vigencia durante mucho tiempo para reaparecer con fuerza en el Renacimiento e imponerse en el siglo XVII5. Así, comienzan a aparecer en Italia los primeros tratados sobre el género novelesco. Alicia Yllera ha trazado las líneas de este período en un interesante y documentado artículo. En él podemos ver cómo la novela carecía de una teoría propia y que serían los tratadistas italianos del XVI los que se la proporcionarían, como así lo explica la autora citada:

Una teoría de la novela independiente surge en Italia, vinculada a la polémica en torno al Ariosto, con las obras de Giraldi Cintio, Pigna y más tarde Malatesta, etc. Se planteaba el problema de cómo enjuiciar el Orlando Furioso y sus gran éxito, siendo así que quebrantaba los principios clásicos (unidad de acción, narración con principio, medio y fin, etc.). ¿Era una obra defectuosa, sólo apta para el disfrute del vulgo, o el modelo de un nuevo género? I Romanzi de Giovanni Battista Pigna aparece en 1554, poco antes que el Discorso intorno al comporre dei romanzi de Giovambattista Giraldi Cintio (1554); aunque Giraldi denunciará la deuda de Pigna, su antiguo discípulo, hacia él. Pigna se propone aplicar a la novela los preceptos aristotélicos aunque, en su deseo de justificar el Orlando, llegue a conclusiones opuestas a las de la Poética. La novela es un género distinto de la épica, aunque existan semejanzas entre ambas. Por lo tanto,sólo parcialmente coinciden sus reglas. La épica se construye sobre la veracidad de la historia o de la fábula; la novela suele ser independiente de la verdad y, al menos parcialmente, inventa sus temas como la comedia; mezcla personajes altos y bajos; prefiere imitar varias acciones de un mismo hombre y no una única acción individual; incluye más digresiones y busca la variedad. Su modelo es el Orlando Furioso. También Giraldi Cintio ahonda las diferencias que separan a la novela de la épica: la novela surgió en Francia, pasó a España y de ahí a Italia, donde los mejores autores, a diferencia de lo que ocurre en otras naciones, las han compuesto en verso y no en prosa. La

5. El Romanticismo trató, por el contrario, de pulverizar las categorías que defendían los géneros preconizando la mezcla de éstos y alegando para ello que el rigor de una clasificación a priori de las obras literarias es una traba para la libertad creadora del autor. Desde entonces se impuso esa idea, que trajo como consecuencia que la noción de género se refiriera en adelante a prototipos más que a formas o a contenidos. 
novela es, para la Italia contemporánea, lo que fueron los poemas heroicos para griegos y romanos, puesto que los nuevos tiempos requieren nuevas formas ${ }^{6}$.

Por lo que respecta a España las artes poéticas en castellano sólo comienzan a aparecer a finales del siglo XVI, cubriéndose la laguna de siglos anteriores con "noticias de poéticas", obras de historiografía, traducciones y comentarios de los clásicos, prólogos, elogios, controversias, etc., siendo de gran importancia las relaciones de España e Italia en el Renacimiento, ya que los humanistas españoles (como los del resto de Europa) se vieron influenciados por el trabajo de los tratadistas italianos (Vida, Daniello, Muzio, Varchi, Giraldi, Cinthio, Pigna, Fracastoro, Minturno, Partenio, Escalígero, Viperano, Patrizzi, Tasso, Denores, Malatesta, Buonamici y Summo).

El primer teorizador poético del siglo de Oro, Alonso López Pinciano, parece ser también el primer español que se preocupa de la teoría del género novelesco. En su obra Philosophia antigua poética, publicada en Madrid en 1596, el Pinciano trata a través de trece epístolas: de la felicidad humana, la doctrina platónica acerca de la literatura, la esencia de la poesía, los géneros poéticos, la fábula, el lenguaje poético, la métrica, la tragedia y sus clases, la comedia, la lírica, la épica, géneros menores, los actores y la representación. El Pinciano estructura su obra como un intento de sistematización de toda la teoría literaria en un cuerpo de doctrina lógico y completo. En el apartado dedicado a la épica parece estar muy influenciado por el del Tasso sobre la novela y el poema heroico ${ }^{7}$.

El Pinciano inserta el género novelesco en la doctrina aristotélica a través de la épica. La novela, que él llama romance, no es más que una clase de épica: la que se basa en la pura ficción. Este es el razonamiento que nos presenta:

Vos, señor Pinciano, lo dezís por los poemas que agora son muy vsados, dichos romances de los italianos, los quales carecen de fundamento verdadero, y de quienes digo assí: no ay diferencia alguna essecial, como algunos piensan, entre la narración común fabulosa del todo, y entre la que está mezclada en historia, quiero dezir, entre la que tiene fundamento en verdad acontecida y entre la que le tiene en pura ficción y fábula; y esto se saca fácilmente de lo que Aristóteles enseña en la doctrina trágica, de la qual dize que puede tener fundamento en historia, como la Ilíada, y puede carecer deste fundamento, como la Flor de Agathón; de manera que ni lo uno ni lo otro pone diferencia essencial alguna, sino, como diximos quando de la tragedia se habló, será más

6. "Teoría de la novela en el siglo XVII (Los principios de la constitución del género novelesco en Francia)", Thélème. Revista española de estudios franceses, 2, (1986), pp.98-99.

7. Sobre el poema heroico y la novela, véase el capítulo $\mathrm{V}$ de la cuarta parte del libro de René BRAY: La Formation de la doctrine classique en France, (Paris: Nizet, 1945), titulado precisamente así: "Le poème héroïque et le roman", pp. 336-349. 


\section{LA NOVELA COMO GÉNERO LITERARIO EN EL SIGLO XVII EN FRANCIA}

verosímil, quanto a este punto,la que en historia se fundamentare que no la otra; de manera que los amores de Theágenes y Cariclea, de Heliodoro, y los de Leucipo y Clitofonte, de Achiles Tacio, son tan épica como la Ilíada y la Eneyda; y todos essos libros de cauallerías, qual los quatro dichos poemas, no tienen, digo, diferencia alguna essencial que los distinga, ni tampoco essencialmente se diferencia uno de otro por las condiciones indiuiduales, ansí como dizen ay diferencia de vn Pedro a otro: y es vna cosa buscar la essencia de la épica, otra buscar la perfección en todas sus qualidades. Será perfecta la heroyca, quanto a la materia, la que se funda en historia más que la que no se funda en alguna verdad (por las causas que en la tragedia se dixeron), mas la que carece de verdadero fundamento, puede tener mucho primor y perfección en su obra, y que en otras cosas aventaje a las que en verdad se fundamentan; yo, a lo menos, más quisiera auer sido autor de la Historia de Heliodora que no de la Farsalia de Lucano (III, pp. 164-166).

La novela se trata como si fuese un apartado dentro del poema épico y no en el concepto que tenemos de novela actualmente; de cualquier modo, la disertación del Pinciano entra dentro de la más pura lógica pues pensemos que el género actual en su tiempo era un género desconocido. El vocablo novela designaba un relato breve, de rápida andadura argumental, a la manera que los novellieri italianos habían puesto de moda; toda narración larga, en prosa y de imaginación, pertenecía al campo de la épica.

A pesar de que se han señalado influencias del Pinciano en la teoría de Cervantes, no es éste un hecho totalmente probado, aunque las ideas del Pinciano pudieron influir al autor del Quijote.

Cuando Miguel de Cervantes escribe la primera parte de Don Quijote de la Mancha, en 1605, aún no adopta el término novela, sino que llama a su obra repetidas veces en el prólogo historia ${ }^{8}$ :

- En lo de citar en las márgenes los libros y autores de donde sacáredes las sentencias y dichos que pusiéredes en vuestra historia...

- Tras esto, para mostraros hombre erudito en letras humanas y cosmógrafo, haced de modo como en vuestra historia se nombre el río Tajo...

- En resolución, no hay más sino que vos procuréis nombrar estos nombres, o tocar en la vuestra estas historias que aquí he dicho...

-Sólo tiene que aprovecharse de la imitación en lo que fuere escribiendo; que cuanto ella fuere más perfecta, tanto mejor será lo que se escribiere. Y pues esta vuestra escritura no mira a más que a deshacer la autoridad y cabida que en el mundo y en el vulgo tienen los libros de caballerías, no hay para qué andéis mendigando sentencias de filósofos, consejos de la Divina Escritura, fábulas de

8. La misma denominación había dado Mateo Alemán a su Guzmán de Alfarache, en 1599, cuando en su "Declaración para el entendimiento deste libro" dice lo siguiente:

Teniendo escrita esta poética historia para imprimirla en un solo volumen... 
poetas, oraciones de retóricos, milagros de santos; sino procurar que a la llana, con palabras significantes, honestas y bien colocadas, salga vuestra oración y periodo sonoro y festivo, pintando, en todo lo que alcanzáredes y fuere posible, vuestra intención; dando a entender vuestros conceptos sin intrincarlos y escurecerlos. Procurad también que leyendo vuestra historia el melancólico se mueva a risa, el risueño la acreciente, el simple no se enfade, el discreto se admire de la invención, el grave no la desprecie, ni el prudente deje de alabarla.

En esta última cita, además del nombre de historia que el autor da a su obra, encontramos gran parte de los ingredientes necesarios del género novelesco: imitación de la realidad, verosimilitud, claridad de estilo, etc. Así ocurre que, aún sin denominar la obra con el nombre actual del género, Cervantes "inventa" y crea la novela moderna, como prometía su prólogo, aun sin definirlo así.

No sólo crea el género en la práctica, sino que le da nombre teórico, pues, en 1613 y en el Prólogo de sus Novelas ejemplares, el autor nos dice:

...Yo soy el primero que ha novelado en lengua castellana, que las muchas novelas que en ella andan impresas, todas son traducidas de lenguas extranjeras, y estas son mías propias, no imitadas ni hurtadas; mi ingenio las engendró, y las parió mi pluma, y van creciendo en los brazos de la estampa.

En la cita Cervantes confirma la relación del autor con "su ficción" desde el punto de vista más intrínseco: la metáfora del parto. En ese momento no es la "novela" de que habla Cervantes muy distinta del cuento largo y, es indudable que el término encierra diversos fines como el de divertir, o el fin moral, aunque parece ser que lo que más le interesa a Cervantes al dirigirse al lector es narrar algunos sucesos para hacer más interesantes las horas desocupadas y de recreo. Sea como fuere, el hecho indudable es que el autor castellano creó el género en su sentido actual (Don Quijote) y adoptó el vocablo difundiéndolo con una práctica adecuada (Novelas ejemplares). Con su obra parece responder contundentemente a la frase del traductor de Giraldi Cinthio, Vozmediano, cuando en 1590 desea que: “... los naturales de España hagan lo que nuncan han hecho, que es componer novela."

\section{Desarrollo del género en Francia}

En Francia la influencia de Cervantes con las dos obras citadas es inmensa, aunque cada una en un género distinto; por lo que respecta al género que nos interesa tratar aquí (novela), desde el momento de su publicación en España no deja de ser conocido El Quijote, primero en forma de traducción de episodios y luego con traducciones completas de la obra o de cada parte. Así, en 1614, sólo nueve años más tarde de la publicación de la obra de Cervantes, aparece una traducción de la primera 
parte debida a César Oudin; en 1618, a los tres años escasos de su publicación en España, aparece la traducción de la segunda parte, realizada por François de Rosset. En el período comprendido entre 1614 y 1810 se cuentan cincuenta y ocho ediciones de cuatro traducciones diferentes de Don Quijote. En 1678 aparece la segunda gran traducción del libro, la de Filleau de Saint- Martin, que conoció ocho ediciones de 1679 a 1700 y renovó el interés por la obra. No obstante, es contradictoria la impresión que el protagonista causa en los lectores y autores franceses que no parecen entender muy bien su especial idiosincrasia; de ahí que la mayor parte de las veces traduzcan episodios sueltos. En general, las numerosas imitaciones y alusiones a la obra en la literatura francesa, ponen su atención únicamente sobre los episodios más cómicos. Boileau parece ser el único que analiza y encuentra la causa psicológica de las desgracias de Don Alonso Quijano: el desfase existente entre la concepción de la vida que tiene el hidalgo español y la que tienen los demás.

Los dos casos más claros de imitación directa del Quijote en la novela del XVII son el Berger extravagant, 1627, de Charles Sorel y el Chevalier hypocondriaque, 1632, de Du Verdier. Sorel será uno de los pocos novelistas que utilice la separación entre el protagonista y su mundo circundante; al querer arremeter contra las novelas sentimentales o pastoriles, traslada a su época el caso de Alonso Quijano: su protagonista se vuelve loco a causa de tantas lecturas de las historias de pastores galantes. Du Verdier nos narra el enloquecimiento de su protagonista de tanto leer Amadís de Gaula.

Aunque la obra de Sorel pretendió lograr en Francia el mismo éxito que Don Quijote en España, la novela pasó sin interés alguno en cuanto a creación literaria. No ocurrió igual con su feroz crítica de los procedimientos de la novela pastoril: su "antiroman" es una perfecta doctrina literaria contra los convencionalismos, exageraciones, mentiras y situaciones falsas de la novela pastoril. Si podía pensarse que después del gran éxito de L'Astrée la novela pastoril iba a alargar su influencia en la novela francesa del XVII, a partir de la publicación del Berger extravagant la novela de D’Urfé deja de ser fuente de inspiración para los narradores franceses. El género pastoril se apagará con L'Astrée, aunque pocas obras han dejado una huella tan fuerte sobre las costumbres y mentalidades de su tiempo: la novela se convirtió en un "manual del bien hablar" y en un modelo de la novela de amor y la novela psicológica, que, curiosamente, no siguió esa línea. En cambio, fue mucho más relevante su influencia en el teatro, concretamente en las tragicomedias y comedias pastoriles.

En cuanto al género novelesco, a pesar de quedar aislada en el universo narrativo, la novela de Honoré d'Urfé ya contenía características de dos de los grandes géneros del siglo XVII: la novela heroica o de aventuras (la tópica del universo aristocrático y galante) y el petit roman o novela histórica (los análisis psicológicos, sobre todo de las obras de Mme de Lafayette).

El otro gran género novelesco, las histoires comiques, se verá impulsado por la picaresca española, que tendrá una importancia decisiva en el desarrollo de la novela. 
El género de la picaresca ya había aparecido en el siglo XVI con la publicación en 1554 de La vida del lazarillo de Tormes y de sus fortunas y adversidades, aunque se asienta definitivamente en 1599 con Mateo Alemán y su Guzmán de Alfarache. El género picaresco reaccionaba contra una delicadeza artificial y la idealización de una sociedad ya desaparecida. El caballero de la Edad Media se ha convertido en aventurero y la plaga de guerras y epidemias que sufre Europa no deja lugar a una galantería fingida sino a estómagos hambrientos que no encuentran ayuda entre sus semejantes. Los títulos más importantes para la novela francesa del XVII son los ya citados Lazarillo y el Guzmán de Alfarache, traducidos varias veces y casi inmediatamente después de su publicación en España, la Vida del escudero Marcos de Obregón, 1618, de Vicente Espinel, y el Buscón de Quevedo que circuló en Francia entre 1603 y 1626; es decir, en las mismas fechas de publicación que en su país de origen.

Así pues, y a excepción del gran éxito de L'Astrée, la novela francesa del XVII se ve dominada por tres grandes corrientes:

- la novela heroica o de aventuras

- las histoires comiques

- el petit roman o nouvelle historique et galante

Consideradas las dos primeras como derivaciones de otras influencias, la novela heroica dependerá en exceso de lo que es el poema épico y las normas del Tasso; por su parte las histoires comiques acusan una gran dependencia de la picaresca española, guardando las distancias lógicas entre la especial idiosincrasia del "pícaro" español y sus émulos franceses. De cualquier forma los dos géneros "filtrarán" su parte positiva para preparar el camino a la novela histórica-galante del período clásico: en un caso el recurso a la historia, en otro la observación de la realidad y sus análisis de las condiciones ambientales.

Conviene dejar sentadas algunas premisas antes de entrar a analizar los distintos tipos de relatos, ya que el XVII es un siglo crucial para la novela. En el siglo XVII la palabra roman designaba las novelas de aventuras y de caballería: amores y hazañas de los caballeros de la Tabla Redonda a la búsqueda del santo Grial, relatos pastoriles poblados de príncipes disfrazados de pastores, relatos de náufragos, historias de piratas y reencuentros con una familia perdida desde hace mucho tiempo. Estos romans, cuya acción se desarrollaba con frecuencia en épocas y lugares lejanos, gozaban de una libertad absoluta en cuanto a acciones y gestas de los personajes, así como en lo que se refería a todo tipo de fenómenos naturales. Las intervenciones mágicas y sobrenaturales eran consustanciales a este tipo de relatos y, en ese aspecto, las innovaciones que representan los personajes de L'Astrée consisten en el incipiente desarrollo de la psicología en los personajes, plasmados por medio de charlas o debates entre los personajes; de cualquier modo estos personajes no parecen ser capaces de distinguir entre la ilusión y la realidad. Por lo que respecta a los teóricos y críticos es claro que sienten una desconfianza total hacia la novela al ser una "forma literaria" nueva, sin tradición; sus lectores más asiduos son los jóvenes y las mujeres (sobre todo éstas) y parece una 
literatura propia para esa edad, ya que alimenta sus sueños de aventuras y de amor. Esto hace que se la defina como un género frívolo que seduce engañosamente y conmueve directamente a los sentidos sin dejar intervenir a la razón. Tanto se vitupera y reprueba a la novela que incluso encontramos referencias y alusiones desdeñosas en los tratados de teatro y poesía. ¿Por qué este odio irracional de los críticos hacia el género novelesco? La explicación más lógica que suelen aducir es que es contrario a la verdad y que perjudica las mentes llenándolas de falsos sueños con obras de pura imaginación y de fantasía.

Paradójicamente, la recepción que le dispensa el público es inmensa y aunque las modalidades evolucionan durante todo el siglo XVII no dejan de contar con el favor de los lectores, en su mayor parte mujeres, como ya hemos dicho, a los que se quiere agradar con los libros, y en los que parecen pensar los autores a la hora de redactar sus obras; así, desde el largo éxito de L'Astrée y el posterior de las novelas "de aventuras" de Gomberville, continuando con los largos relatos heroicos de La Calprenède y Scudéry hasta las novelas históricas de la época de Luis XIV, los autores verán sus obras continuamente reeditadas y gozar del favor de un público femenino cada vez mayor. Para otro tipo de lectores, con una moral más libre y no tan convencional, las histoires comiques calmarán sus ansias de evasión, fundadas en acontecimientos más "reales" o "creíbles".

La deducción que se puede sacar de esta multiplicidad y variedad de géneros es reveladora: la novela ha empezado a entrar en la literatura y el gusto de los lectores la va a imponer en contra de la opinión de la crítica; ésta, o bien se rinde a la evidencia o bien terminará haciéndose oir en el desierto. Claro que, antes de que ocurra lo primero y tengan que ocuparse de la novela como género literario, serán los propios novelistas los que se encarguen de exponer sus teorías en avertissements, préfaces, avis au lecteur y otras prácticas al uso, hecho que demuestra que la teoría de la novela durante el período barroco se encuentra, sobre todo, en prólogos o dentro de la obra misma en forma de digresiones del narrador o en boca de los personajes, en sus conversaciones o discusiones sobre un relato incluido dentro de la novela9.

Así, Gomberville, para explicar el desorden de las distintas versiones de Polexandre y su continua transformación, explicita, en 1637, en un Avertissement aux honnêtes gens la cuestión del siguiente modo:

Je crains tout ce qui est capable d'assujettir ma liberté; un grand dessein ne me déplaît pas, parce qu'il est bientôt imaginé, mais l'exécution m'en est insupportable parce qu'il y faut beaucoup de temps, beaucoup d'attention, beaucoup de servitude et beaucoup d'ordre. L'irrégularité de mon esprit ne peut souffrir

9. Coincido, y la comparto plenamente, con esta afirmación de Alicia Yllera en su artículo ya citado (p. 97). 
ces importunes et perpétuelles justesses. Il se plaît au désordre. Il aime les dérèglements. ${ }^{10}$

Diríase que Gomberville hace suyas las teorías de Théophile de Viau sobre la manera de componer sus obras, expuestas en los versos 119-120 de la Elégie à une dame:

"La règle me déplaît, j’écris confusément/jamais un bon esprit ne fait rien qu'aisément."

En cualquier caso, parece ser que la intención de Gomberville, a pesar de su desorden y negligencia, es ofrecer al lector lo que está de moda, ya que no olvidemos que gran parte del período en el que redacta las cuatro versiones de su famosa novela la literatura está dominada por la tragicomedia y los autores de este tipo de obras tienen los mismos argumentos que la novela de aventuras de Gomberville. Lo que hace el autor en su novela es transformar el caballero medieval en un caballero refinado del XVII, es decir reflejar en su obra los personajes y costumbres de la sociedad de su época.

La intención de Gomberville de rivalizar con el género literario que se impone en su tiempo, es la misma que parece guiar a los dos novelistas más famosos y leídos de todo el siglo: La Calprenède y Mlle de Scudéry ${ }^{11}$. Para este propósito, lógico es que adopten las reglas de la tragedia, o que las ajusten lo más posible a las de sus novelas heroicas. Esto es lo que hace La Calprenède que incluso ya había escrito y representado diez tragedias y tragicomedias antes de dedicarse a la novela o a las histoires como el prefiere que se denomine a sus obras, para recalcar el carácter histórico con que están revestidas. Según él, el argumento de estas histoires debe ser único y los episodios deben limitarse a adornar la intriga principal; el tiempo no debe sobrepasar el espacio de un año; la acción central debe desarrollarse en un único lugar. Posiblemente donde La Calprenède se muestre más original es en la concepción que tiene de la creación literaria como disfrute y diversión para el creador ya que, al contrario que todos sus coetáneos, afirma que su única finalidad es la del propio divertimento.

Por lo que concierne a la aplicación de la regla de la unidad de acción, esta no es tan estricta en todos los géneros; así por ejemplo, la unidad de la epopeya es menos severa que la de la tragedia, ya que la materia de una epopeya puede suministrar varios argumentos de tragedia. La aclaración es pertinente si tenemos en cuenta el hecho de que La Calprenède adapta para sus obras las reglas estrictas de la tragedia (que por otra parte no le eran desconocidas pues se había iniciado en ese género), siendo en

10. Tomo V de la edición completa de L'Exil de Polexandre, Paris: T. du Bray et A. Courbé, 1637.

11. Suponiendo que escribiera ella las novelas que se le atribuyen, hecho que no está probado y parece imposible hacerlo a pesar de que varios estudiosos se han consagrado al problema. Lo más probable es que los dos hermanos compusieran las obras a medias, bien distribuyéndose el trabajo por capítulos, bien partes concretas o pasajes específicos. 
cambio las reglas de la epopeya las que parecen escoger los hermanos Scudéry en su Préface a la primera novela atribuida a Madeleine de Scudéry: Ibrahim ou l'Illustre Bassa, en 1641. En efecto, en lo que es considerado la expresión más acabada de la poética de la novela de su época, y quizás de todo el siglo XVII, los hermanos Scudéry desarrollan análisis que tratan de la invención y de la disposición del poema épico. Podríamos ordenar las diferentes consideraciones emitidas por los Scudéry ${ }^{12}$. en dos grandes secciones; la primera concierne a la disposición de la acción: a imitación de los "Anciens", el novelista debe de concebir una única acción principal, de la que dependan estrechamente las acciones secundarias:

J'ay donc vû dans ces fameux Romans de l'Antiquité qu'à l'imitation du Poëme Epique, il y a une action principale, où toutes les autres sont attachées; qui règne par tout l'ouvrage; et qui fait qu'elles n'y sont employées, que pour la conduire à sa perfection (...) afin que par cet enchainement ingénieux toutes les parties ne facent qu'un corps et que l'on n'y puisse rien de détaché ny d'inutile.

Siguiendo el mismo ejemplo de los clásicos, el novelista debe comenzar su relato in medias res, e imaginar una acción cuya duración no exceda de un año:

... avec une adresse incomparable (les Anciens) ont commencé leur Histoire par le milieu, afin de donner de la suspension au Lecteur, dès l'ouverture du Livre: et pour s'enfermer dans des bornes raisonnables, ils ont fait (et moy après eux) que l'Histoire ne dure qu'une année.

Las restantes reflexiones del Prefacio tratan de lo que los Scudéry consideran la piedra angular de la construcción novelesca: la verosimilitud. Con el fin de conferir al argumento la mayor credibilidad posible, las aventuras narradas deben inscribirse dentro de una realidad histórica:

... pour donner plus de vray-semblance aux choses, i'ay voulu que les fondemens de mon Ouvrage fussent historiques, mes principaux personnages marquez dans l'Histoire véritable, comme personnes illustres, et les guerres effectives. C'est sans doute par cette voye que l'on peut arriver à sa fin. Car lorsque le mensonge et la vérité sont confondus par une main adroite; l'esprit a peine à les démesler, et ne se porte pas aisément à détruire ce qui luy plaist.

de ahí, la observación de las costumbres de los países donde se sitúa la acción: “... i'ay observé pour cela les moeurs, les coustumes, les loix, les religions, et les inclinations des peuples".

y de ahí, la eliminación de las peripecias extravagantes:

12. En este punto el desconcierto es aún mayor, ya que la obra la publica Georges Scudéry, se le atribuye a la hermana pero es muy posible que el Prefacio, que habla de un sólo autor: "Je ...", fuese de Georges Scudéry. 
Nous avons autrefois veû des Romans qui nous produisoient des Monstres, en pensant nous faire voir des miracles: leurs Autheurs, pour s'attacher trop au merveilleux, ont fait des grotesques, qui tiennent beaucoup des visions de la fièvre chaude (...) C'est par cette raison encor que ie n'ay point causé tant de naufrages, comme il y en a dans quelques anciens Romans (...) Ce n'est pas que ie prétends bannir les naufrages des Romans; ie les approuve aux Ouvrages des autres, et ie m'en sers dans le mien. Ie sçay mesme que la Mer est la Scène la plus propre à faire de grands changements; et que quelques uns l'ont nommée le Théâtre de l'Inconstance. Mais comme tout excès est vicieux, ie ne m'en suis servy que modérément, por conserver le vraysemblable.

Todo esto sería insuficiente para establecer la verosimilitud del argumento si el novelista no tuviese el deseo de aspirar a la verdad psicológica. Así, la acción debe conducir a la descripción de las almas:

Après avoir descrit une avanture, un dessein hardy, ou quelque événement surprenant, capable de donner les plus beaux sentimens du monde; certains Autheurs se sont contentez de nous asseurer, qu'un tel Héros pensa de fort belles choses sans nous les dire, et c'est cela seulement que ie désirois sçavoir. Car que sçay-ie si dans ces événemens la Fortune n'a point fait autant que luy? si la valeur n'est point une valeur brutale? s'il a souffert en honneste homme les malheurs qui luy sont arrivez? Ce n'est point par les choses de dehors; ce n'est point par les caprices du destin, que ie veux iuger de luy, c'est par les mouvemens de son âme, et par les choses qu'il dit.

En principio el Prólogo se presentaba como una síntesis de ideas ya sabidas y que habíamos visto, por ejemplo, en La Calprenède. Otras como la de la vraisemblance ya habían sido suficientemente tratadas por Chapelain en 1623 ("La vraisemblance est l'object immuable de la poésie" o "La vraisemblance et non la verité sert d'instrument au poète pour acheminer l'homme à la vertu”), el propio Georges Scudéry en la querella del Cid contra Corneille, Balzac, Le Moyne y otros autores, hasta llegar a Boileau que en su Art poétique, 1674, se inclinaba por la verosimilitud de este modo contundente:

Jamais au spectateur n'offrez rien d'incroyable:

Le vrai peut quelquefois n'être pas vraisemblable.

Une merveille absurde est por moi sans appas:

L'esprit n'est point ému de ce qu'il ne croit pas. ${ }^{13}$

(Canto III versos 47-50).

13. Nunca al espectador le mostréis lo increíble: lo verdadero puede no ser muy verosímil. La maravilla absurda no me ofrece atractivo: no se emociona el alma por algo que no cree. 
Lo cierto es que el autor del Prólogo insiste en sus argumentos de manera reiterada al creer que sus contemporáneos han fracasado al llevar a la práctica la teoría de la novela-epopeya y que Scudéry quiere hacer triunfar ya que piensa que la novela, o el género novelesco, es la forma en prosa de la epopeya.

El triunfo que pretendía Scudéry para esta forma en prosa de la epopeya llegó pero fue efímero. Hacia 1670 estos largos relatos caen en un profundo olvido y ya nadie los lee o los que lo hacen, como Mme de Sévigné y La Fontaine, lo confiesan no sin rubor. Los críticos se quejan de que los autores presentan a unos héroes tan perfectos que resultan inimitables y exasperantes así como también la monotonía de su psicología, cosa que no es siempre cierta si leemos algunas de las definiciones o explicaciones de sus personajes. En Ibrahim ou l'Illustre Bassa la princesa Axiamire expresa su aversión por el matrimonio y su miedo por la pasión con estas palabras:

Par cette passion qui dérègle l'esprit, qui détruit la raison et qui trouble le repos de l'âme de ceux qu'elle possède, je n'en suis point capable... ce n'est que l'artifice des hommes qui nous a persuadé que cette passion n'était point vicieuse.

Ciertamente sus personajes evolucionan de Ibrahim a Le Grand Cyrus y Clélie, haciéndose cada vez más grandes y heroicos y asumiendo una dimensión que los situa por encima de los simples mortales al tiempo que los aleja del lector. A esto hay que añadir algo inapelable ¿qué lector soportaría obras de tantas páginas?, pues Ibrahim constaba de 3.004, Artamène ou le Grand Cyrus de 13.095, Clélie, histoire romaine de 7.316 y Almahide ou l'esclave reine de 6.516. Esta última novela, inacabada en un principio, la terminó Madeleine de Scudéry en 1663, y no osó imprimirla porque, decía ella, "personne ne voudrait l'acheter ou le lire".

Si la preponderancia de la novela de aventuras y heroica tiene lugar entre $1625 \mathrm{y}$ 1660, prácticamente entre las mismas fechas, y de modo paralelo, se desarrolla otro tipo de obras que sus autores denominaron histoires comiques. Este nombre aparece por primera vez en una obra de Vérité Habanc, publicada en París en 1585 con el título de Nouvelles histoires tant tragiques que comiques, volviendo a utilizarlo, en 1612, un autor no muy relevante, Du Souhait, en un libro que publica simultáneamente en París y Troyes: Histoires comiques ou entretiens facetieux. Jean Serroy describe muy acertadamente los inicios del género, en un libro dedicado a este tipo de relatos:

L'Histoire comique naît dans la plus profunde obscurité. Parmi tous les écrivains sans talent qui, dans les premières années du XVIIe siècle, sacrifient aux goûts du jour, un provincial, qui se prend pour un bel esprit, a l'idée de composer un recueil de contes facétieux, por amuser les princes qui le font vivre. Comme il manque d'imagination, il va chercher son bien chez le conteurs du siècle précédent; et, désireux de donner un titre original à une oeuvre qui ne l'est pas, il décide de l'appeler Histoires comiques. Le titre, évocateur dans sa concision, va être repris par des écrivains de plus haute volée qui lui donneront, 
eux, un contenu neuf, et feront de l'Histoire comique une des tentatives romanesques les plus originales du siècle ${ }^{14}$.

Desde el punto de vista de la creación novelesca las histoires comiques son una especie de cajón de sastre en el que tienen cabida todas las tendencias: libertina, autobiográfica, filosófica, de viajes imaginarios, etc. Quizás por ello, y por estar basadas únicamente en la libertad de creación del propio autor, este tipo de obras atraigan a autores tan diferentes como Théophile de Viau, Sorel, Tristan 1'Hermite, Scarron, Cyrano de Bergerac y Furetière. Entre estos escritores "de haute volée", crean lo más destacable del género, sobresaliendo tres obras fundamentales: L'Histoire comique de Francion, Le Roman comique y Le Roman bourgeois ${ }^{15}$. Entre la obra de Charles Sorel, publicada en 1623, y la de Antoine Furetière, publicada en 1666, se desarrolla el género cuyo primer hito y posiblemente el más significativo de todas las histoires comiques es el Francion de Sorel, una de las obras de ficción que más se reimprimió durante todo el XVII. Francion 16. reúne influencias de los narradores del Renacimiento (Rabelais, Noël du Fail, Béroalde de Verville), de las facecias populares, de los autores satíricos contemporáneos y de la novela picaresca española. La influencia de la picaresca española está en la base de lo que algunos denominan novela realista, de Francion a Gil Blas de Lesage. Es preciso aclarar, en este punto, que el mismo realismo que forma la esencia de la novela picaresca excluye una influencia directa y literal que sería precisamente la negación del realismo, en tanto que este es observación de la vida real y no utilización de un tema literario. Francion debe a las novelas picarescas españolas (sobre todo a Lazarillo de Tormes, Guzmán de Alfarache, Marcos de Obregón y El Buscón don Pablos) características muy concretas: una composición deshilvanada, cuya hilazón reside en la existencia individual del protagonista y su continuidad cronológica; el carácter de autobiografía ficticia; la alternancia de éxitos y fracasos, y no la curva regular de una ascensión o de una decadencia que marcan la progresión de la acción; la alegre aceptación del protagonista de los adversos accidentes que le ocurren; la gran variedad de los incidentes que le ocurren a lo largo de su itinerario o errancia.

14. Jean Serroy, Roman et Réalité. Les histoires comiques au XVIIe siècle, Paris: Librairie Minard, 1981 (1re. éd. Presses Universitaires de Grenoble, 1980), pp. 23-24.

15. La importancia de las "Histoires comiques", así como de las tres obras citadas, podemos deducirla por el hecho de que Antoine Adam en la edición de "La Pléiade", dedicada a novelistas franceses del siglo XVII, incluya cuatro obras: tres "Histoires comiques" y La Princesse de Clèves (Paris: Gallimard, 1958).

16. Al hablar de la obra de Sorel nos referimos siempre a los siete libros de la edición de 1623 y no a los añadidos posteriores de 1626 y 1633, hasta un total de doce. Se puede afirmar que el espíritu del verdadero Francion, como así lo quiso Sorel en la primera edición, sólo está en los siete primeros libros ya que las ediciones y "reformas" posteriores obedecen a una intención de moralizar, acorde con los deseos del Cardenal Richelieu que no permitía veleidades ni osadías innecesarias; el proceso de Théophile es revelador a este respecto. 
Francion es ante todo una historia divertida y como su título bien indica una histoire comique, entendiendo por comique lo que pertenece a la vida cotidiana lo que entra en el campo de la comedia, situaciones que se asemejan a la realidad trivial; más tarde, Sorel lo explicará detenidamente en su Bibliothèque françoise:

On parle des romans comiques en général, mais on les divise aussi en satyriques et en burlesques, et quelques-uns sont cela tout ensemble. Les bons romans comiques et satyriques semblent plutôt être des images de l'histoire que tous les autres. Les actions communes de la vie étant leur object, il est plus facile d'y rencontrer de la vérité. Pour ce qu'on voit plus d'hommes dans l'erreur et dans la sottise qu'il y en a de portés à la sagesse, il se trouve parmi eux plus d'occasions de raillerie, et leurs défauts ne produisent que la satire. On rencontre là plutôt le genre vraisemblable que dans les pièces héroïques qui ne sont que fictions, puisqu'il y a peu d'hommes qui méritent d'être estimés des héros, c'est-à-dire quelque chose entre les dieux et les hommes ${ }^{17}$.

El propósito de Sorel en su novela es muy claro y así lo explicita el autor en el Avertissement d'importance aux lecteurs: “De m'amuser à descrire une histoire qui tinst d'avantage du folastre que du serieux." asimismo, el autor se preocupa de dar un tono consistente a su novela y a su estilo:

Et moy je n'escry que pour mettre en ordre les conception que j'ay euës longtemps auparavant. Ils s'amusent à parler d'un nombre infiny de choses vaines, qui ont esté dites beaucoup de fois, et ne penetrent point jusqu'au centre de la vérite: pour moy j'essaye d'aborder par un chemin droit un souverain bien et une vertu solide.

Sorel, que desea mostrar a los lectores: "toutes les choses dans leur naïvité" y de describirles las acciones "sans dissimulation", cree firmemente que la descripción de las condiciones o de los estados puede y debe renovar la literatura novelesca; así, remedando exageradamente el hablar de la galantería, el de los pedantes, el de los nobles y el de los campesinos Sorel pretende crear un nuevo estilo y su obra nos propone "otro" lenguaje distinto al habitual: "Quoy que c'en soit, ces resveries là contienennent des choses que jamais personne n'a eu la hardiesse de dire."

Este mismo aspecto de novedad en las intenciones lo encontramos también en el Prefacio de una curiosa novela de André Mareschal y que podríamos incluir dentro de las histoires comiques: La Chrysolite ou le secret des romans, publicada en París por el editor Thomas du Bray en 1627. Fundamentando su libro en la verdad y no en la concepción de un nuevo lenguaje o estilo de vida, como Sorel, Mareschal nos confiesa: "Je fais profession de dire le vray, le plus qu'il m'est possible."

17. La Bibliothèque françoise, Paris:, Compagnie des Libraires du Palais, 1664. 
Esta intención de decir la verdad, es decir de contar hechos reales asimilando la ficción a lo verdadero para que el propio lector no pueda distinguirlo de lo falso, es la base de toda la novela:

Si tout ce que j'ay mis dedans ce livre est vray, il en est plus recommendable: que s'il est faut, et que tout sorti de mon invention, je puis dire sans vanité, que l'artifice y doit estre bien grand, qui a sceu donner de si belles apparences de la verité, et un visage si naturel et si serieux a des imagination sans corps.

El Prefacio de Mareschal contiene una sólida argumentación contra los novelistas que no se inspiran en la realidad cotidiana; así, condena las convenciones, la estética de la hipérbola, la invesorimilitud de las tempestades, naufragios, guerras, travestimentos, etc. Según Mareschal en la mayor parte de las novelas "à peine se trouve-t-il rien de solide, rien de vray-semblable ny que se puisse rapporter aux moeurs et à la puissance des hommes, ou au véritable cours du temps et des siècles". Por esta razón, el escritor nos presenta de modo lapidario la preocupante degradación quimérica a la cual han conducido a la novela los escritores "idealistas":

Jusques icy tous ceux qui se sont piqués en ce genre d'écrire, nous ont vendu le fard pour le vray teint, et ont donné une face à leurs livres qui pour estre pleine de piperies et de mensonges, et d'impossibilités, a pu entretenir et abuser beaucoup d'esprits.

Para solucionar todos los problemas que plantean las novelas a las que Mareschal critica, el escritor volverá a las costumbres de su propia época:

Icy, je n'ay rien mis qu' un homme ne pust faire, je me suis tenu dedans les termes d'une vie privée, afin que chacun se pust mouler sur les actions que je descris... J'ay attaché des actions à un nom particulier et supposé, afin que plusieurs le pussent prendre pour eux, sans que je leur donasse. Peut-estre que le tout est une feinte; mais cette feinte touchera plusieurs, s'ils veulent ne se feindre point ny se déguiser à eux-mesmes; et pourvu que cela arrive, voylà le fruit et le secret de mon roman, et celuy que tous les autres devraient avoir.

La extrapolación de la vida cotidiana en la novela intenta ser tan fiel que Mareschal indica a su lector:

Lecteur, si tu veux avoir un contentement parfaict, imagine toy seulement que ce Roman est une Histoire, ou plustost tous les deux ensemble: tu y trouveras par tout des choses si semblables à celles qu'on appelle véritables, que tu m'advouëras, après les avoir leuës, que si elles ne sont que pures fantaisies, c'est tout ce que l'on peut imaginer selon le temps, et que le mensonge ne fut jamais mieux habillé des couleurs de la vérité. 
Así, la obra de Mareschal no es que sea verosímil sino que es verdadera. Como defiende Antoine Adam ${ }^{18}$ esta novela pretende, y con razón, no ser una novela sino únicamente el relato exacto de un acontecimiento verdadero. Por primera vez nos encontramos con una novela realista en el sentido moderno de la palabra. Señalar por último que incluso el final nada convencional de la novela, consagrando la separación de los dos amantes, rompe asimismo con toda la tradición anterior y sirve de bisagra o punto de encuentro entre Les Angoisses douloureuses de Marguerite de Brief y el renunciamiento trágico de la heroína de Madame de Lafayette.

No nos extrañemos de que los novelistas, más que todos los demás escritores que escriben obras que corresponden a géneros consagrados, sientan la necesidad de explicarse en los prólogos de sus obras. Estos prólogos, como ya hemos podido comprobar en Ibrahim, son a veces más importantes que las propias obras, bien por su valor intrínseco bien porque el libro queda supeditado a aplicar los principios que el novelista defiende en los mencionados Préfaces, Avertissement aux lecteurs, Avis aux lecteurs, etc. Esto es lo que parece ocurrir con el importante Avertissement aux lecteurs que a modo de prólogo precede a la novela con que Charles Sorel vuelve al género de las histoires comiques, que con tanto éxito había ensayado en 1623. En efecto, Polyandre. Histoire comique, publicada en 1648, es una obra sustentada en la reflexión sobre la creación novelesca, siendo ésta quizás la razón mayor de su fracaso ya que, recogiendo la opinión de Maurice Lever:

Rien, en effect, de moins spontané que ce roman, que semble fait surtout pour servir d'illustration aux théories de l'auteur. Peu de romanciers contemporains eurent une conscience aussi nette que Sorel, de ce qui distingue le vrai du vraisemblable. Qu'est-ce donc pour lui que la vraisemblance? Une vérité littérai$r$, aussi éloignée des conventions idéalistes que de la déformation satirique, qui s'apparente à la vérité historique, sans pourtant s'identifier pleinement à elle. Entre le romanesque chimérique et la caricature du monde réel, Sorel milite pour une peinture sincère, objective, "naïve", mais non servile, de la nature. Le roman dit "vraisemblable" ne se définit donc pas comme un miroir fidèle de la réalité, mais comme la projection de cette réalité sur le champ de la littérature ${ }^{19}$.

El Avertissement aux lecteurs de Polyandre es tan importante para las histoires comiques como lo había sido siete años antes el de Ibrahim ou l'Illustre Bassa para las novelas heroico-épicas ya que presenta, de la manera más clara, una definición de la histoire comique que reivindica un status autónomo y afirma el carácter respetable y digno de un tipo de novelas que, al haber sido tradicionalmente asimiladas a la literatura menor

18. Histoire de la littérature française au XVIIe siècle, Tome I, Paris: Editions Mondiales, 1962, p. 157.

19. M. Lever: Le Roman français au XVII siècle, Paris: P.U.F, 1981, pp.146-148. 
de simple y puro divertimento, no ocupan en la jerarquía novelesca el lugar que le corresponde. Según Sorel:

La vraye Histoire comique selon les préceptes des meilleurs Autheurs, ne doit estre qu'une peinture naïve de toutes les diverses humeurs des hommes, avec des censures vives de la plupart de leurs deffaux, sous la simple apparence de choses joyeuses, afin qu'ils en soient repris lors qu'ils y pensent le moins.

Las opiniones de Sorel son importantes ya que el autor tiene una conciencia clara y nítida de que el novelista debe decidir libremente su argumento y la forma de llevarlo a cabo según sus propios criterios. Sorel es, en este aspecto, el primero que intenta abandonar los espejismos de las ficciones novelescas y reclama para su obra el derecho de desarrollarse acorde a los esquemas del autor; es decir, una total libertad de transposición al libro de la idea del escritor sin estar sujeto a normas, reglas, preceptos o leyes que la coarten.

Sorel no logró imponer sus ideas con la celeridad que hubiera sido de desear para bien del género novelesco ya que en 1648 a la sociedad francesa no le interesa lo más mínimo la descripción de sus costumbres burguesas ni la mediocridad de la vida cotidiana. El interés de los autores por la vida contemporánea y la observación de las costumbres se acrecienta a partir de 1660, aunque no están aún en total consonancia con el gusto de los lectores. Hacia 1670 los escritores ya se atreven a nombrar a sus personajes con nombres franceses, detalle revelador del cambio de gusto en el público y de una nueva mentalidad estética en los autores.

Pero en el siglo XVII los Avertissements y Préfaces no bastan para establecer la legitimidad del género novelesco, sino que es preciso añadirles la autoridad de eruditos y doctos desarrollos que lo justifiquen en el plano de su existencia relacionándolo, tanto como sea posible, a una tradición literaria ya existente. Respondiendo quizás a la necesidad de llenar este vacío el prelado y erudito Pierre-Daniel Huet redacta el primer texto teórico sobre la novela: Traité de l'origine des romans, ensayo escrito en 1666 y que publica en 1670, encabezando la primera parte de la Zaïde de Mme de Lafayette ${ }^{20}$. Huet intenta dotar de cartas de nobleza a la novela relacionándola con la epopeya para así legitimar su antigüedad. En un ensayo de carácter esencialmente histórico Huet se ocupa del origen de la novela, como indica el título de su obra:

La rudesse et la politesse, menent souvent les hommes à une même fin, qui est l'étude des fictions, des fables et des romans. De-là vient que les nations le plus barbares aiment les inventions romanesques, comme les aiment les plus polies (...). Cette inclination aux fables, qui est commune à tous les hommes, ne

20. Dado que la novela se publica con Segrais como autor, Huet dirige a éste la disertación de su Traité. Existe una edición moderna de la obra (Genève: Slatkine Reprints, 1970), reimpresión de la edición de 1799. 


\section{LA NOVELA COMO GÉNERO LITERARIO EN EL SIGLO XVII EN FRANCIA}

leur vient pas par raisonnement, par imitation, ou par coutume: elle leur est naturelle: et a son amorce dans la disposition même de leur esprit et de leur âme; car le desir d'apprendre et de savoir est particulier à l'homme, et ne le distingue pas moins des autres animaux que sa raison (...) l'ame cherche dans le passé et dans l'avenir, dans la vérité et dans le mensonge, dans les espaces imaginaires, et dans l'impossible même, de quoi les occuper et les exercer ${ }^{21}$.

No obstante, Huet también diserta sobre la novela barroca, intentando formular sus reglas:

Autrefois, sous le nom de Romans, on comprenait, non-seulement ceux qui étaient écrits en prose, mais plus souvent ceux qui étaient écrits en vers. Le Giraldi et le Pigna, son disciple, dans leurs Traités de Romanzi, n'en reconnaissent presque point d'autres, et donnet le Boiardo, et l'Arioste pour modeles. Mais aujourd'hui l'usage contraire a prévalu, et ce que l'on appelle proprement Romans sont des fictions d'aventures amoureuses, écrites en prose avec art, pour le plaisir et l'instruction des lecteurs. Je dis des fictions, pour les distinguer des histoires véritables. J'ajoute, d'aventures amoureuses, parce que l'amour doit être le principal sujet du Roman. Il faut qu'elles soient écrites en prose, pour être conformes à l'usage de ce siècle. Il faut qu'elles soient écrites avec art, et sous de certaines regles; autrement ce sera un amas confus, sans ordre et sans beauté. La fin principale des Romans, ou du moins celle qui doit l'être, et se doivent proposer ceux qui les composent, est l'instruction des lecteurs, à qui il faut toujour faire voir la vertu couronnée, et le vice châtié. Mais comme l'esprit de l'homme est naturellement ennemi des enseignemens, et que son amour-propre le révolte contre les instructions, il le faut tromper par l'appas du plaisir, et adoucir la sévérité des préceptes, par l'agrément des exemples, et corriger ses défauts en les condamnant dans un autre. Ainsi le divertissement du lecteur, que le Romancier habile semble se proposer pour but, n'est qu'une fin subordonnée à la principale, qui est l'instruction de l'esprit, et la correption des moeurs; et les Romans sont plus ou moins réguliers, selon qu'ils s'éloignent plus ou moins de cette définition et de cette fin 22 .

Casi al mismo tiempo que Huet, Charles Sorel dedica a la teoría de la novela una gran parte de su obra De la Connaissance des bon livres ${ }^{23}$. Así, en el capítulo II: De l'histoire et des romans, avec la préférence de l'histoire, compara los méritos de la novela con los de la historia. Adoptando el mismo método que en las alegaciones contradictorias propias de la antigua retórica, de la tradición de los colegios o de los infor-

21. Op.cit., pp.107-110.

22. Ibídem, pp.2-5.

23. Charles Sorel, De la connaissance des bons livres, Paris: André Pralard, 1671 (Existe una edición moderna de L. Moretti Cenerini, Roma: Bulzoni, 1974). 
mes jurídicos en los tribunales Sorel analiza sucesivamente la "Censure des romans" y "Leur défense"24.

Pero la obra teórica que marca la transición entre la novela barroca y la novela de la época clásica, responde al título de Sentiments sur les Lettres et sur l'Histoire avec des Scrupules sur le Style. Calificada en su aparición por el Mercure galant como el mayor acontecimiento literario de principios de 1683, el libro se atribuyó posteriormente a un tal Du Plaisir, considerado por prestigiosos críticos de nuestros días como el autor de una excelente y magnífica "arte poética" de la nouvelle-galante o nouvelle-petit roman. Philippe Hourcade, autor de la última edición crítica de los Sentiments, tampoco escatima elogios para el libro y su autor al afirmar que: "Jusqu'à Du Plaisir ou ne trouve pas de véritable théorie du roman, genre méprisé par les uns ou confondu par les autres avec l'épopée. 25

Dentro de lo que es la renovación del género novelesco, y por lo que respecta a los distintos nombres con que se publican las obras, proceden unas líneas aclaratorias. A partir de 1660 aproximadamente, el vocablo nouvelle denomina indistintamente a narraciones breves (veinte o treinta páginas) y verdaderas novelas (doscientas a trescientas páginas). La expresión nouvelle galante aparece hacia 1670, y la de nouvelle historique la emplea por primera vez el historiador y novelista Saint-Réal como subtítulo de su novela Dom Carlos, en 167226. Como además muchas de estas obras llevan el añadido de nouvelle historique-galante y con frecuencia sus autores las califican de petit roman, la confusión llega a ser enorme. Un ejemplo basta para demostrarlo; en el Avertissement del Prince de Condé, nouvelle historique (1675) su autor, Boursault dice lo siguiente:

24. Añadamos, para completar el cuadro de tratados sobre la novela, que Jean Chapelain compuso en 1647 un Dialogue sur la lecture des vieux romans, (Paris: Nizet, 1971) defendiendo las novelas francesas medievales y que no se publicó hasta 1870 . Por lo que respecta a las relaciones de la novela con la epopeya y la historia, mucho antes de los tratados de Huet y Sorel un texto anónimo de 1626: Le Tombeau des Romans, où il est discours contre les romans, pour les romans, estudia las conexiones entre novela-epopeya-historia y se preocupa por las afinidades y analogías entre verosimilitud y verdad. De la segunda mitad de siglo son los tratados de Saint-Réal (De l'usage de l'histoire, Paris: 1971), del Père René Rapin (Réflexions sur la poétique de ce temps et sur les ouvrages des poètes Anciens et Modernes, Paris: 1674 existe una edición crítica de E.T. Dubois: Genève: Droz, 1970-) y del Père Le Bossu (Traité du poème épique, 2 vol., Paris: Michel Le Petit, 1675).

25. Philippe Hourcade, Sentiments sur les Lettres et sur l'Histoire avec des Scrupules sur le style de Du Plaisir, Genève: Droz, T.L.F., 1975, p. 8.

26. César Vichard, el abate Saint-Réal (1629-1692) en su calidad de historiador y novelista se ocupó ampliamente de las relaciones entre historia y novela, del mismo modo que ya antes que él lo habían hecho el anónimo autor de Le Tombeau des Romans (1662), Pierre-Daniel Huet (1670) y Charles Sorel (1671). Saint-Réal publicó en 1670 su ensayo De l'usage de l'histoire; en él, el historiador deja hablar a los hechos y el novelista los comenta. Para Saint-Réal "Etudier l'histoire c'est étudier les motifs, les opinions et les passions des hommes pour en connaître tous les ressorts, les tours et les détours, enfin toutes les illusion qu'elles savent faire aux esprits, et les surprises qu'elles font aux coeurs" (De l'usage de l'histoire, p. 4.) 
Ce n'est ici qu'un petit roman à quoi l'on prête des noms illustres pour le faire recevoir plus favorablement, parce que l'on est plus sensible aux aventures d'un prince que l'on connaît qu'à celles d'un héros que l'on ne connaît pas.

Una conclusión, sin embargo, puede sacarse de toda esta confusión: lleven un nombre $\mathrm{u}$ otro estos relatos cortos, que quizás se pueden englobar todos bajo el epígrafe de petit roman 27 , suponen una renovación de lo que hasta entonces había sido la novela francesa del XVII, bien en su vertiente de Histoires comiques o en la de Romans hérö̈ques. En adelante la futura novela francesa se basará fundamentalmente en este tipo de obras, haciendo caer en el más absoluto de los olvidos las largas novelas de La Calprenède o Mlle de Scudéry.

La poética de esta nueva forma de novelas, que hemos englobado bajo la denominación de petit roman, es el problema tratado por Du Plaisir en su tratado teórico ya citado: Sentiments sur les Lettres et sur l'Histoire avec des Scrupules sur le style. La segunda parte de esta obra, la que concierne a "l'Histoire", es la relacionada con la cuestión a dilucidar, puesto que lo que Du Plaisir llama Histoire es el género intermediario entre la nouvelle y el roman; es decir, lo que hemos designado como petit roman. Los Sentiments sur l'Histoire llenaron un vacío importante en su tiempo ya que si no faltaban libros sobre el estilo de la conversación o sobre el arte epistolar, teorizar sobre cuales debían ser las reglas para escribir adecuadamente una novela constituía un proyecto sin precedentes. Los Sentiments no guardan ninguna similitud con los libros de crítica anteriores; en el libro no se alude a ningún escritor (es decir no se toma partido por alguien en contra de otro) ni a ninguna obra reciente, si exceptuamos La Prazimène ${ }^{28}$. Desechando el aspecto polémico con que estaban revestidos los tratados teóricos, Du Plaisir intenta ser metódico, exhaustivo y objetivo, siguiendo el principio fundamental de buscar la adhesión del lector a los principios que él defiende, ya que sin la supuesta buena voluntad de aquél la novela no tiene sentido. Du Plaisir comienza sus Sentiments sur l'Histoire discerniendo qué clase de narración es más apta para el espíritu francés. Afirma luego que el novelista no debe interrumpir el hilo de la acción con episodios, conversaciones o digresiones que no tengan relación con la intriga principal; tampoco debe situar la acción en tiempos y países remotos, sino extraer una argumento de la Historia reciente. Según él el escritor debe cuidar la vraisemblance y los incidentes no deben ser extraordinarios, sino encadenarse del modo más normal; a su vez el novelista debe "desaparecer" del relato y no tomar partido por sus personajes, por el contrario, deberá mantenerse imparcial obedeciendo a las leyes de la objetividad. Después de disertar sobre los incidentes y los caracteres adecuados

27. Frédéric Deloffre en su libro La Nouvelle en France à l'âge classique (Paris: Didier, 1967), dedica un capítulo a esta cuestión titulado: "La Ruine du roman et le triomphe des petits genres 1660-1680".

28. Novela escrita por Le Maire y publicada entre 1638 y 1643. 
al relato que preconiza Du Plaisir pone de relieve la difícil tarea del novelista al analizar los sentimientos y esboza, brevemente, lo que para él sería la histoire galante:

Il n'y a pas de moindres difficultés sur les mouvements du coeur que sur les traits de l'esprit. Il faut des lumières très grandes pour pénétrer jusqu'au fond de cet abîme, pour ne point s'égarer parmi tant de diversités, pour toucher vivement des matières si imperceptibles, et pour expliquer des choses qui par le peu de connaissance qu'on en a eu jusqu'ici, n'ont presque point encore de termes propres... Ces qualités sont générales; il en est de plus particulières et qui regardent la composition de l'histoire. Je ne parlerai de ces dernières que comme j'ai parlé des précédentes et des lettres, c'est-à-dire en surface, sans faste de législateur, et avec un esprit de soumission pour tous les conseils qu'on voudra donner contre la practique de ceux-ci.

L'histoire galante est un assemblage de traits divers qui ont besoin d'une matière sur laquelle ils soients tracés, et cette matière est le temps et la scène où se sont passées les actions qui forment cette peinture. On donne dès l'ouverture de l'histoire une idée du lieu et du règne que l'on a choisis. On fait entendre si c'est de la paix ou de la guerre que naîtront les principaux noeuds, et toutes ces choses doivent être exprimées dans la première période. ${ }^{29}$

Una vez realizadas estas consideraciones generales Du Plaisir desciende a otras particulares como los rasgos del cuerpo, las cualidades del alma, el lenguaje "poli" del novelista, los pretextos innecesarios puestos al servicio de la intriga, la naturalidad de los diálogos, etc. En resumen, los Sentiments sur l'Histoire defienden la estética de un nuevo modo de narración (lo que su autor llama romans nouveaux o nouveaux romans: histoires, histoires galantes, nouvelles) con el cual el lector puede verse identificado o ser cómplice de él.

Un bosquejo final de lo que representa la novela durante el siglo XIII nos presenta un cuadro muy preciso que parte de lo que será la extinción de la novela caballeresca, a principios de siglo, y los relatos pastoriles o "bergeries" que tienen su culminación y decadencia con L'Astrée, pudiendo confluir los dos modelos en la tópica de un universo galante, platónico y aristocrático. Desde 1620 la novela que triunfa es la llamada heroica, de aventuras o histórica, concediéndose una enorme importancia, como hemos visto, a los prólogos y pretendiendo dignificar el género con los principios de la epopeya. De un modo paralelo se desarrollan las "histoires comiques" o "romans réalistes" que se alargan hasta la época clásica, momento en que se produce un predominio de otro tipo de relatos: la "nouvelle historique" o "histoire galante" y que impera durante el último tercio del siglo no sólo con estos nombres, sino también con los de "aventures", "relations", o "mémoires", pero prácticamente nunca más con el de "romans", ya que como bien se afirma en un reciente estudio sobre el género

29. Op.cit., pp.52-53. 
novelesco en el XVII: "parce que ce forme est alors devenu synonyme de lourdeur des règles, complication de l'intrigue, excès des caractères, artifice de la composition et du style. C'est que le concept romanesque est passé, en l'espace de cinquante ans, du registre poétique au régistre historique."30

Las innovaciones que presenta la teoría de Du Plaisir y el status autónomo que reivindicaban algunos autores de Histoires comiques (Sorel en particular) para sus obras, son reflejo de la novedad que presenta la novela en el siglo XVII. La interrogación sobre la propia identidad del género ya no recae sólo sobre el contenido de la novela, sino que cuestiona también la relación del autor con su obra; la presencia del autor establece entre él, su libro y el lector, una relación variable pero inevitable. Esta situación, que ya había sido esbozada por Rabelais desde su perspectiva de "conteur" y por Marguerite de Brief desde el análisis de su "yo" se da de manera clara en el XVII en que la búsqueda de lo que es la novela pasa por la búsqueda del novelista, que intenta fijar su status con relación a su obra y con relación a su lector. Se intuyen ya las vastas posibilidades de un sistema triangular (autor-obra-lector) de múltiples variantes y posibilidades inagotables. Los autores del siglo XVIII y sobre todo Diderot, se van a encargar de llevarlo a la práctica.

\section{Bibliografía selecta}

BARAT, J. C. (1978), Théorie des genres et communication, Bordeaux-Talance: Maison des Sciences de l'Homme.

CALVO, J. H. (1984), "La crítica de los géneros literarios”, P. Aullon de Haro (éd.), Introducción a la crítica literaria actual, Madrid: Playor, pp. 83-139.

COHEN, R. (1986), "History and Genre”, New Literary History, 17, pp. 203-218.

CORTI, M. (1972), "I Generi letterari in prospettiva semiologica", Strumenti Critici, 17 , pp. $1-18$.

DEMERSON, G. (1984), La notion de genre à la Renaissance, Genève: Slatkine.

DUCROT, O. et TODOROV, T. (1972), Dictionnaire encyclopédique des sciences du langage, Paris: Seuil.

DUBROW, H. (1982), Genre, London: Methuen.

FOWLER, A. (1982), Kinds of Literature. An Introduction to the theory of Genres and Modes, Oxford: Clarendon Press.

FRYE, N. (1969), Anatomie de la critique, Paris: Gallimard.

FUBINI, M. (1973), “Genesi e storia dei generi letterari”, Critica e poesia, Rome: Bonacci, pp. 121-212.

30. Annick Boileve-Guerlet, Le Genre Romanesque. Des théories de la Renaissance italienne aux réflexions du XVIIe siècle français, Universidade de Santiago de Compostela: Servicio de Publicaciones e Intercambio Científico, 1993, p. 264. 
GARRIDO GALLARDO, M. A. (1988), Teoría de los géneros literarios, Madrid: Arco/Libros S.A.

GENETTE, G. (1979), Introduction à l'architexte, Paris: Seuil.

GENETTE, G. (1986), Théorie des genres, Paris: Seuil.

HEMPFER, K. W. (1973), Gattungstheorie, Munich: Fink.

JAKOBSON, R. (1973), Questions de poétique, Paris: Seuil.

JAUSS, H. R. (1970), “Littérature médièvale et théorie des genres”, Poétique, 1, pp. 79-101.

JOLLES, A. (1972), Formes simples, Paris: Seuil.

KIBEDI-VARGA, A. (1970), Rhétorique et littérature, Paris: Didier.

SEGRE, C. (1985), “Generi letterari”, Principios de análisis del texto literario (trad. del ital.), Barcelona: Crítica, pp. 268-296.

STEMPEL, W. D. (1970-71), "Pour une description des genres littéraires", Actes du XIIe Congrès International de Linguistique et Philologie Romanes, Bucarest: Editura Republici Socialiste Romània, II, pp. 565-570.

TODOROV, T. (1970), Introduction à la littérature fantastique, Paris: Seuil.

TODOROV, T. (1978), Les genres du discours, Paris: Seuil.

TODOROV, T. (1981), Mikhaïl Bakhtine. Le principe dialogique, Paris: Seuil.

VIETOR, K. (1977), “L’histoire des genres littéraires”, Poétique, 32, pp. 490-506.

WELLEK, R. et WARREN, A. (1971), La théorie littéraire, Paris: Seuil.

ZUMTHOR, P. (1972), Essai de poétique médiévale, Paris: Seuil. 